\title{
Identification of Serratia marcescens SE1 and determination of its Herbicide 2,2- dichloropropionate (2,2-DCP) Degradation Potential
}

\author{
Eleanor $\underline{\text { Abel }}^{1^{*}}$, Nurhafizah $\underline{\mathrm{lbrahim}}^{2}$ and Fahrul $\underline{\text { Huyop }}^{1}$ \\ ${ }^{1}$ Department of Industrial Biotechnology, Faculty of Biosciences and Bioengineering, Universiti Teknologi Malaysia, \\ 81310 Skudai, Johor, Malaysia \\ ${ }^{2}$ Faculty of Science and Biotechnology, University Selangor, Jalan Timur Tambahan, 45600 Bestari Jaya, Selangor, \\ Malaysia \\ E.mail: eleanor abel@ymail.com
}

Received $8^{\text {th }}$ May 2012; Received in revised form 24 ${ }^{\text {th }}$ May 2012; Accepted $1^{\text {st }}$ June 2012

\begin{abstract}
Aims: The goal of the study is to isolate species of bacteria that capable of utilizing 2,2-dichloropropionic acid (2,2-DCP) as sole carbon source from soil sample collected from surrounding lake water located in Universiti Teknologi Malaysia, Skudai Johor.

Methodology and Result: Genomic DNA from bacterium SE1 was extracted and PCR amplification was carried out using universal primers, Fd1 (5' - AGA GTT TGA TCC TGGCTC AG - 3') and rP1 (5'- ACG GTC ATA CCT TGT TAC GAC TT - 3') before sending for sequencing. The 16S rDNA nucleotide sequences were compared with Basic Local Alignment Search Tool nucleotide (BLASTn) and further analyzed using phylogenetic tree of Neighbour-Joining method (MEGA 5). Phylogenetic analysis indicated that SE1 strain clearly shared $97 \%$ homology to the genus of Serratia marcescens and therefore designated as Serratia marcescens sp. SE1. SE1 exhibited the ability to utilize 2,2-DCP as sole carbon source at $20 \mathrm{mM}$ concentration with cell doubling time of $5 \mathrm{~h}$ and maximum chloride ion release of $38 \mu \mathrm{molCl}-/ \mathrm{ml}$. This result suggests that the dehalogenase enzyme present in the bacteria has high affinity towards the substrate. Based on morphological and partial biochemical characteristics, strain SE1 was a non-motile Gram-negative bacterium with red colonies, that gave a catalase positive reaction.

Conclusion, significance and impact of study: A better understanding of dehalogenases enzyme produce by this Serratia marcescens sp. SE1 in general will be useful to be used as bioremediation tools for environmental management. This is the first reported case that Serratia sp. has the ability to degrade halogenated compound.
\end{abstract}

Keywords: 2,2-dichloropropionic acid, 16S rDNA, Phylogenetic analysis, Serratia sp.

\section{INTRODUCTION}

2,2-dichloropropionic acid (2,2-DCP) is a chlorinated aliphatic herbicide that has a wide action on plants, especially grasses and monocots. According to World Health Organization (1990), 2-3\% of applied pesticides are effectively used in mitigating pest in agricultural industry, however, the rest of the pesticides remain in the soil. The residual pesticides come in contact with water, causing surface and ground water pollution, which lead to the toxicity to the ecosystem. Therefore, bioremediation technique in treating pesticides residual in soil and water sources is vital.

Dehalogenase enzyme play key roles in the detoxification of halogenated compound, which widely used in agriculture and industry over the last 100 years as solvents, defatting agents, herbicides and pesticides or as intermediates for chemical synthesis. Microorganisms capable of utilizing halogenated aliphatic hydrocarbons as sole sources of carbon and energy are widely distributed and a large number of them have been isolated
(Chaudhry and Chapalamadagu, 1991; Ghosal et al., 1985; Hardman, 1991; Leisinger and Bader, 1991). Microorganisms capable of degrading 2,2-DCP are readily present in contaminated sources. Therefore, it is essential to isolate, identify and characterize the microorganisms that exist.

Although halogenated compounds are commonly found in soil and on the surface and groundwater, studies have shown that these halogenated compound exhibit potential threats to human, animal and the ecosystem (Haggblom, 1992; Lee et al., 1998). Microorganisms cause natural degradation of the halogenated compounds which might convert parent compounds to intermediates or less toxic compounds. However, natural bioremediation is a slow process and needs to be enhanced by the action of the potential microorganisms. Herbicide 2,2-DCP (Figure 1) or $\alpha$ - haloalkanoic acid can be used to control specific annual and perennial grasses such as quick grass, Bermuda grass and cattails. According to Allpress and Gowland (1998), dehalogenase is an interesting class of enzymes to study because it has been proposed that they 
provide environmental defense mechanism for microorganisms. The isolation and identification of dehalogenase producing bacteria were well studied (Jing and Huyop, 2008; Jing et al., 2008; Ismail et al., 2008; Thasif et al., 2009; Zulkifly et al., 2010).

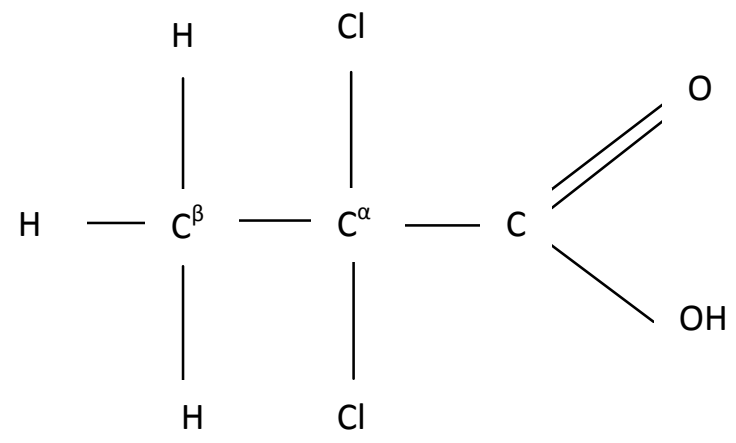

Figure 1: Structure of 2,2-dichloropropionic acid.

Bacteria taxonomy using 16S rDNA is a common method in the characterization and identification of microorganism (Wang et al., 1995). Bacterial 16S rDNA gene sequences have been widely used in reconstructing phylogenies. Molecular approach has been used for bacterial phylogeny and is of major importance for species definition and identification (Clariddge, 2004; Fredericks and Relman, 1996; Raoult et al., 2004; Rossello-Mora and Amann, 2001).

In contrast to the 16S rDNA identification, the BIOLOG ${ }^{\mathrm{TM}}$ GEN III MicroPlate ${ }^{\mathrm{TM}}$ is a system that utilizes automated biochemical methodologies that tests a microorganism's ability to utilize or oxidize a panel of 94 carbon sources (Miller and Rhoden, 1991). The Biolog system was originally created for the identification of pathogenic Gram negative bacteria but since high demand of this system in 1989 , the capability of the instruments in identification has widened and it's also include identification of Gram positive bacteria (Stager and Davis, 1992). In this paper, the properties of a newly isolated bacterium from soil that are able to utilize 2,2-DCP as the sole source of carbon and energy will be described based on both techniques of molecular and biochemical identification.

\section{MATERIALS AND METHODS}

\section{Chemicals}

Halogenated compounds were obtained from Sigma Chemical Co. (USA). Other chemicals were of analytical grade.

\section{Isolation and identification of 2,2-DCP degrading bacteria}

Sample was collected from soil surrounding lake water located in Universiti Teknologi Malaysia (UTM) Skudai, Johor. Fresh samples were placed onto Luria-Bertani (LB) agar plates containing $1.0 \%$ tryptone, $0.5 \%$ yeast extract and $1.0 \%$ sodium chloride $(\mathrm{NaCl})$. The plates were incubated at $30{ }^{\circ} \mathrm{C}$ and examined after $16 \mathrm{~h}$. After incubation, several colonies were selected and streaked onto fresh LB agar medium and cultured for $16 \mathrm{~h}$ at $30^{\circ} \mathrm{C}$ to obtain a pure colony.

\section{Bacterial growth on halogenated compound}

The pure colony was grown in 2,2-DCP liquid medium and incubated overnight on rotary shaker $150 \mathrm{rpm}$ at $30^{\circ} \mathrm{C}$. Stock solution was prepared as $10 \mathrm{x}$ concentration of basal salts containing $\mathrm{K}_{2} \mathrm{HPO}_{4} 3 \mathrm{H}_{2} \mathrm{O} \quad\left(42.5 \mathrm{~g} \quad \mathrm{~L}^{-1}\right)$, $\mathrm{NaH}_{2} \mathrm{PO}_{4} .2 \mathrm{H}_{2} \mathrm{O}\left(10.0 \mathrm{~g} \mathrm{~L}^{-1}\right)$ and $\left(\mathrm{NH}_{4}\right)_{2} \mathrm{SO}_{4}\left(20.0 \mathrm{~g} \mathrm{~L}^{-1}\right)$. The trace metals salts solution was a $10 \mathrm{x}$ concentrate that contained nitriloacetic acid $\mathrm{C}_{6} \mathrm{H}_{9} \mathrm{O}_{6} \quad\left(\begin{array}{lll}1.0 & \mathrm{~g} & \mathrm{~L}^{-1}\end{array}\right)$, $\mathrm{MgSO}_{4} .7 \mathrm{H}_{2} \mathrm{O}\left(2.0 \mathrm{~g} \mathrm{~L}^{-1}\right), \mathrm{FeSO}_{4} .7 \mathrm{H}_{2} \mathrm{O}\left(120.0 \mathrm{mg} \mathrm{L}^{-1}\right)$, $\mathrm{MnSO}_{4} .4 \mathrm{H}_{2} \mathrm{O}\left(30.0 \mathrm{mg} \mathrm{L}^{-1}\right), \mathrm{ZnSO}_{4} .7 \mathrm{H}_{2} \mathrm{O}\left(30.0 \mathrm{mg} \mathrm{L}^{-1}\right)$ and $\mathrm{CoCl}_{2} .6 \mathrm{H}_{2} \mathrm{O}\left(10.0 \mathrm{mg} \mathrm{L}^{-1}\right)$ in distilled water (Hareland et al., 1975). Minimal media for growing bacteria contained $10 \mathrm{ml}$ of $10 \mathrm{x}$ basal salts and $10 \mathrm{ml}$ of $10 \mathrm{x}$ trace metal salts per $100 \mathrm{ml}$ of distilled water and were autoclaved $\left(121^{\circ} \mathrm{C}\right.$ for $15 \mathrm{~min} 15 \mathrm{psi})$. Carbon source (2,2-DCP) was separately sterilized by filtration and added aseptically to the media to desired final concentration of $20 \mathrm{mM}$. In order to prepare solid medium, bacteriological agar $(1.5 \% \mathrm{w} / \mathrm{v})$ was added prior to sterilization. Samples were removed periodically and the growth was determined by measuring turbidity at $A_{680 n m}$

\section{Chloride ion released in growth medium}

Enzyme activity was measured by determining the release of chloride ion during dehalogenation reaction using a colorimetric method (Bergman and Sanik, 1957). Sample $(1 \mathrm{~mL})$ was added into $100 \mu \mathrm{L}$ of $0.25 \mathrm{M}$ ammonium ferric sulphate in $9 \mathrm{M}$ nitric acid and mixed thoroughly. Mercuric thiocyanate-saturated ethanol $(100 \mu \mathrm{L})$ was then added and the solution was mixed by vortexing. The color was allowed to develop for $10 \mathrm{~min}$ and chloride ion liberation at $\mathrm{A}_{460 \mathrm{~nm} \text {. }}$

\section{S rDNA gene sequencing}

Bacterial DNA was extracted from bacterial cultures grown on $20 \mathrm{mM}$ 2,2-DCP minimal media using Wizard® Genomic DNA Purification Kit. The polymerase chain reaction (PCR) was carried out to amplify the target DNA fragments using universal primers, Fd1 (5' - AGA GTT TGA TCC TGG CTC AG - 3') and rP1 (5' - ACG GTC ATA CCT TGT TAC GAC TT - 3') (Fulton and Cooper, 2005). DNA amplification was performed for 30 cycles and the PCR cycle was set as initial denaturation $94^{\circ} \mathrm{C}$ for $5 \mathrm{~min}$, followed by cooling, denaturation $94 \stackrel{\circ}{\circ} \mathrm{C}$ for $1 \mathrm{~min}$, annealing $55^{\circ} \mathrm{C}$ for $1 \mathrm{~min}$ and final extension $72 \stackrel{\circ}{\circ} \mathrm{C}$ for 10 min. Amplicons were purified using QIAGEN ${ }^{\circledR}$ QIAquick PCR purification kit and sequenced by $1^{\text {st }}$ Base ${ }^{\circledR}$ company (Malaysia).

\section{Phylogenetic analysis}

The 16S rDNA gene sequence was compared with GenBank database using BLAST to determine the genetic similarities of the isolates (Altschul et al., 1997). 
Phylogenetic tree was constructed using neighbor-joining method from profile alignment command of CLUSTAL W from MEGA 5 (Saitou and Nei, 1987).

\section{Scanning electron microscope}

Bacteria were grown with dialysis membrane until the log phase. The dialysis membrane were then soaked and dried for the next process. Fixation process using fixation buffer $(2.5 \%$ glutaraldehyde buffer) was carried out followed by incubation for $4 \mathrm{~h}$ in room temperature. The dialysis membrane was rinsed 3 times for $15 \mathrm{~min}$ at room temperature with $0.1 \mathrm{M}$ phosphate buffer. The fixed cells were dehydrated with a serial concentration (30 to $95 \%$ ) of ethanol for every $10 \mathrm{~min}$ and followed by $100 \%$ ethanol for $20 \mathrm{~min}$. The cells were substituted with $100 \%$ acetone for $20 \mathrm{~min}$ and then freeze dried. The cells were coated with gold and were examined with a scanning electron microscope (JEOL JSM6390LV).

\section{BIOLOG ${ }^{\mathrm{TM}}$ GEN III MicroPlate Identification}

Biolog is a commercial tool for identify unknown bacterium. It analyzes microorganism in 94 phenotypic tests: 71 carbon source utilization assays and 23 chemical sensitivity assays. The test panel provides a "Phenotypic Fingerprint" of the microorganism which can then be used to identify up to species level. This is an important breakthrough for determining the species or strains of bacteria present in a soil. The isolate to be identified is grown on agar medium and then suspended in a special "gelling" inoculating fluid (IF) at the recommended cell density. Then the cell suspension is inoculated into the GEN III MicroPlate, $100 \mu \mathrm{L}$ per well and the MicroPlate is incubated to allow the phenotypic fingerprint to form. All of the wells start out colorless when inoculated. During incubation there is increased respiration in the wells where cells can utilize a carbon source and/or grow. Increased respiration causes reduction of the tetrazolium redox dye, forming a purple color. Negative wells remain colorless, as does the negative control well with no carbon source. There is also a positive control well used as a reference for the chemical sensitivity assays. After incubation, the phenotypic fingerprint of purple wells is compared to Biolog's extensive species library. If a match found, a species level identification of the isolates will be made. Most identification will be obtained after 13 to $24 \mathrm{~h}$ period.

\section{RESULTS}

\section{Isolation and identification of 2, 2-DCP degrading bacteria}

After about more than a month of enrichment cultures, a bacterium able to utilize 2,2-DCP as sole carbon and energy source was isolated from the mixture of collected samples from UTM lake. Characteristics of physiological and biochemical reactions are described in Table 1(a) and 1(b).

Table 1(a): Morphological and biochemical characteristics of the isolated bacterium

\begin{tabular}{ll}
\hline Parameters & Properties \\
\hline Strain & SE1 \\
Identified species & Serratia marcescens \\
Cell shape & Rod \\
Size $(\mu \mathrm{m})$ : Diameter & $0.12 \pm 0.03$ \\
\multicolumn{1}{c}{ Length } & $2.0 \pm 1.0$ \\
Gram staining & Gram Negative \\
Colony & Bright red color \\
Margin (Outer edge of colony) & Entire \\
Elevation & Umbonate \\
Oxygen requirement & Facultative anaerobes \\
Motility & - \\
Catalase & + \\
Indole & - \\
Spore stain & - \\
Oxidase & - \\
Citrate & + \\
Gelatin Liquefaction & + \\
Glucose fermentation broth & + \\
Lactose fermentation broth & - \\
\hline "+" for positive result; “““ for negative results
\end{tabular}

The basic cellular morphologies are shown in Figure $\mathbf{2 a}$ and $\mathbf{2 b}$. The bacterium was rod shaped with smooth edged red colonies.
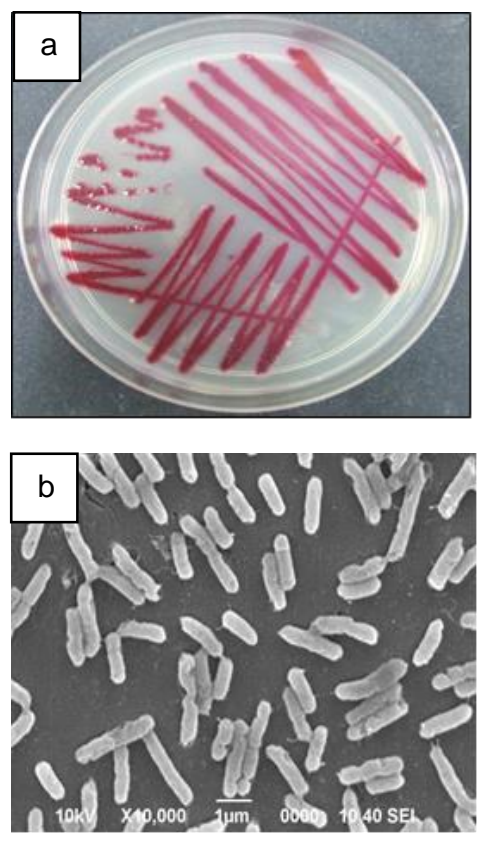

Figure 2: (a) SE1 growth on Luria Bertani (LB) media after $16 \mathrm{~h}$ at $30^{\circ} \mathrm{C}$.

(b) Scanning electron micrograph of SE1 bacterial isolates under $10,000 \mathrm{X}$ magnification.

Table 1(b): Extensive biochemical analysis of strain SE1 using BIOLOG ${ }^{\mathrm{TM}}$ GEN III Microplate.

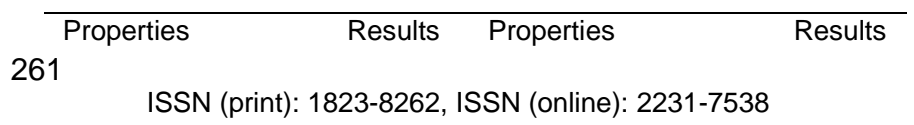




\begin{tabular}{|c|c|c|c|}
\hline Dextrin & + & D-Fucose & + \\
\hline D-Maltose & + & D-Glucose-6-PO4 & + \\
\hline D-Trehalose & + & L-Glutamic Acid & + \\
\hline D-Cellobiose & + & Glucuronamide & + \\
\hline Gentiobiose & + & -Keto-Glutaric Acid & + \\
\hline Sucrose & + & Acetoacetic acid & - \\
\hline D-Turanose & - & $\begin{array}{l}\text { N-Acetyl-D- } \\
\text { Mannosamine }\end{array}$ & + \\
\hline Stachyose & + & L-Fucose & + \\
\hline D-raffinose & - & D-Fructose-6-PO4 & + \\
\hline D-glucose & + & L-Histidine & + \\
\hline D-sorbitol & + & Sodium Bromate & - \\
\hline Gelatin & + & D-Malic Acid & + \\
\hline Pectin & + & Sodium Butyrate & + \\
\hline D-Glucuronic Acid & + & $\begin{array}{l}\text { N-Acetyl-D- } \\
\text { Galactosamine }\end{array}$ & + \\
\hline D-Lactose & - & Potassium Tellurite & - \\
\hline D-Mannose & + & Vancomycin & + \\
\hline Glycyl-L-Proline & + & L-Malic Acid & + \\
\hline $\begin{array}{l}\text { D-Galacturonic } \\
\text { Acid }\end{array}$ & + & Acetic Acid & + \\
\hline Methyl Pyruvate & + & Tetrazolium Violet & + \\
\hline Inosine & + & Tetrazolium Blue & + \\
\hline D-Fructose & + & L-Serine & + \\
\hline D-Arabitol & + & Guanidine HCL & + \\
\hline L-Alanine & + & Niaproof 4 & + \\
\hline $\begin{array}{l}\text {-Hydroxy -Butyric } \\
\text { Acid }\end{array}$ & - & $\mathrm{pH} 6$ & + \\
\hline $\begin{array}{l}\text {-Methyl-D- } \\
\text { Glucoside }\end{array}$ & + & $1 \% \mathrm{NaCl}$ & + \\
\hline D-Galactose & + & $4 \% \mathrm{NaCl}$ & + \\
\hline Myo-inositol & + & $8 \% \mathrm{NaCl}$ & - \\
\hline L-Arginine & + & $1 \%$ Sodium Lactate & + \\
\hline D-Gluconic Acid & + & Fusidic Acid & + \\
\hline L - Lactic Acid & + & Lincomycin & + \\
\hline D - Serine & + & Trolerandomycin & + \\
\hline $\begin{array}{l}\text { N-Acetyl-D- } \\
\text { Glucosamine }\end{array}$ & + & Rifamycin SV & + \\
\hline D-Salicin & + & Aztreonam & + \\
\hline 3-Methyl Glucose & + & Lithium Chloride & + \\
\hline Glycerol & + & Nalidixic Acid & - \\
\hline L-Aspartic Acid & + & -Keto-Butyric Acid & - \\
\hline $\begin{array}{l}\text { P-Hydroxy- } \\
\text { Phenylacetic acid }\end{array}$ & + & Citric Acid & + \\
\hline
\end{tabular}

The $1.6 \mathrm{~kb}$ of the PCR product of $16 \mathrm{~S}$ rDNA was amplified (Figure 3). The PCR product was sent for DNA sequencing. A complete sequence (1600 bp) of the 16S rDNA of strain SE1 was determined and similarity search by BLASTn was done. BLASTn results showed highly identity to Serratia marcescens (Table 2). From the results, the 2,2-DCP degrading bacterium was designated as Serratia marcescens SE1. In order to show the relationship strain SE1 among dehalogenase producing bacteria, a number of representatives of dehalogenase producing bacteria were selected for construction of a phylogenetic tree (Figure 4).

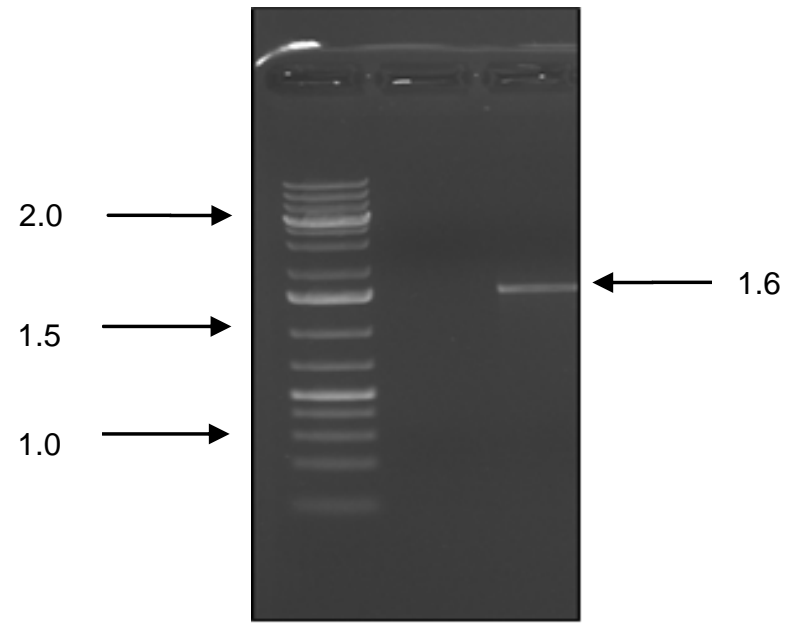

Figure 3: PCR amplification of $16 \mathrm{~S}$ rDNA gene on an agarose gel $(0.8 \%)$.

Lane 1: $1 \mathrm{~kb}$ DNA ladder

Lane 2: Control (without Fd1 primer)

Lane 3: An approximately $1.6 \mathrm{~kb}$ amplified 16S rDNA DNA fragment

Table 2: The BLASTn results according to NCBI database

\begin{tabular}{llc}
\hline Accession No. & Description & $\begin{array}{c}\text { Max Identity } \\
(\%)\end{array}$ \\
\hline EU371058 & $\begin{array}{l}\text { Serratia marcescens } \\
\text { HL1 } \\
\text { ADBX01000007.1 }\end{array}$ & $\begin{array}{l}\text { Serratia odorifera } \\
\text { 4Rx13SOOg }\end{array}$ \\
ACXA01000088.1 & $\begin{array}{l}\text { Klebsiella sp. 1_1_SS } \\
\text { Cont1.88 } \\
\text { Escherichia coli }\end{array}$ & 97 \\
AEXD01000004.1 & $\begin{array}{l}\text { STEC_7v gec7v.contig.3 } \\
\text { Escherichia coli } \\
\text { AEXD01000017.1 }\end{array}$ & 96 \\
& $\begin{array}{l}\text { STEC_7v } \\
\text { gec7v.contig.16 }\end{array}$ & 96 \\
\hline
\end{tabular}

The phylogenetic tree shows that Serratia marcescens SE1 is a closer relative of Rhodococcus sp. HN2006A and Pseudomonas sp.S3 (Hamid et al., 2010). It is more distant to Pseudomonas sp. R1.

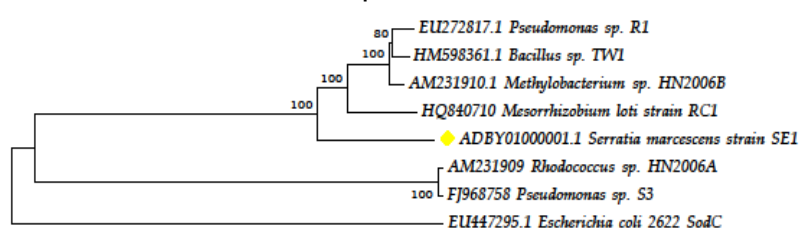

$\longmapsto 0.05$

Figure 4: Phylogenetic relationship between SE1 and dehalogenase producing bacteria based on 16S rDNA gene sequences. (Bar: $5 \%$ dissimilarity). E.coli 2622 SodC is used as the control (out-group) organism.

\section{Bacterial growth on halogenated compound}

Bacterium SE1 was grown in minimal medium supplied with $20 \mathrm{mM} \mathrm{2,2-DCP}$ at $30^{\circ} \mathrm{C}$. Growth was measured

Lane $\quad 1 \quad 2 \quad 3$


every $4 \mathrm{~h}$ time interval and from the growth experiment, it showed that the cell's doubling time was approximately 5 h. Bacterium SE1 was also grown on other halogenated substrate, for example 2,3-dichloropropionic acid (2,3-CP), 3-chloroproponic acid (3-CP) and Monochloroacetate (MCA). However, no growth was observed in all of the substrates used.

\section{Chloride ion released in growth medium}

The maximum amount of chloride ion released was found to be $38 \mu \mathrm{molCl}^{-} \mathrm{mL}^{-1}$ from growth at $20 \mathrm{mM} \mathrm{2,2-DCP}$. This indicates bacterium SE1 able to degrade 2,2-DCP as sole source of carbon and energy.

\section{DISCUSSION}

In this paper, we identify the isolation of a single bacterial strain from UTM lake side using 16S rDNA gene analysis, that effectively dechlorinate 2,2-DCP. According to the biochemical test, SE1 could grow and utilized 2,2-DCP as sole source of carbon and energy. The genus Serratia has high potential to degrade halogenated compound by producing dehalogenase enzyme. In terms of doubling time, Serratia grew faster than Rhizobium sp. as reported by Allison et al. (1983). In general, shorter doubling time shows the fastest rate of utilizing the 2,2-DCP. The observation maybe due to the high efficiency of the dehalogenase enzyme expression and also the uptake system present in the bacterium. In contrast, slow growth is due to low efficiency in the expression of dehalogenase enzyme and poor in bacterial uptake system. Slater et al. (1995) described 2,2-DCP is one of the toxic halogenated compounds that commonly used by some bacteria as their sole carbon and energy for growth.

Serratia marcescens is a motile, short rod-shaped, Gramnegative, facultative anaerobe bacterium, classified as an opportunistic pathogen (Hejazi and Falkiner, 1997). Serratia marcescens is ubiquitous which commonly found in soil, water, plants and animals. It is widely present in non-potable water in underdeveloped countries due to poor chlorination. Serratia marcescens is well known for the red pigmentation it produces called prodigiosin. Prodigiosin is a member of the family prodiginines which only produced by some Serratia species (Venil et al., 2009; Sundaramoorthy et al., 2009). Ke et al. (2005) had described the isolation of Serratia marcescens strain GT596 from soil, possesses high chondroitinase AC activity that may be of value for various biotechnological applications.

Ventura and Zink (2002) stated that 16S rDNA genes sequencing and analysis has become one of the cornerstones of modern microbial taxonomy. Therefore, these sequences are used to define genus specific for a rapid detection of bacterial species. However, 16S rDNA gene sequences are normally not sufficient to differentiate strains within a species, which BIOLOG $^{\circledR}$, however, sometimes can. In contrast this molecular tool was helpful in assessing the overall phylogenetic relationship between the most typical bacteria. From previous study, it has found that $\mathrm{BIOLOG}{ }^{\circledR}$ could be a valuable complement to other methods for confirmation but using it as a single method for identification could be misleading. The major advantage of the 16S rDNA gene sequencing is that the $16 \mathrm{~S}$ rDNA gene is present in all bacteria and is a universal target for bacterial identification and provides high accuracy for identification of any bacterial organism, reliability and reproducibility (Drancourt et al., 2004; Kolbert and Persing, 1999).

\section{CONCLUSION}

In conclusion, this study provides the identity of dehalogenase producing bacteria isolated from UTM lake side. On the basis of morphological, partial biochemical characteristics, BIOLOG identification, 16S rDNA sequencing and its placement on the phylogenetic tree, the bacteria had a close evolutionary relationship with Serratia marcescens SE1. However future studies on dehalogenase enzymes is necessary for a greater understanding of the degradation of 2,2-DCP and its related compounds. It is hoped that more studies would be possible to isolate organism with desired characteristic and can be used along with a consortium of other bacteria for proper degradation of halogenated compounds.

\section{ACKNOWLEDGEMENTS}

The author would like to thank Universiti Teknologi Malaysia for financing this work under GUP and Ministry Of Higher Education No. QJ130000.7135.00H34.

\section{REFERENCES}

Allison, N., Skinner, A. J. and Cooper, R. A. (1983). The dehalogenases of a 2,2 dichloropropionate degrading bacterium. Journal of General Microbiology 129, 1283 - 1293.

Allpress, J. D. and Gowland, P. C. (1998). Dehalogenases: Environmental defense mechanism and model of enzyme evolution. Biochemical Education 26, 267 - 276.

Altschul, S. F., Madden, T. L., Schaffer, A. A., Zhang, J., Zhang, Z., Miller, W. and Lipman, D.J. (1997). Gapped BLAST and PSI-BLAST: a new generation of protein database search programs. Nucleic Acid Research 25 (17), 3389 - 3402.

Bergman, J. G. and Sanik, J. Jr. (1957). Determination of trace amounts of chlorine in Naphtha. Analytical Chemistry 29, 241 - 243.

Chaudhry, G. R. and Chapalamadagu, S. (1991). Biodegradation of halogenated organic compounds. Microbiological Reviews 55, 59 - 79.

Clariddge, J. E. (2004). Impact on 16S rRNA gene sequence analysis for identification of bacteria on clinical microbiology and infectious disease. Clinical Microbiology Review 17, 840 - 862.

Drancourt, M., Berger, P. and Raoult, D. (2004). Systematic 16S rRNA gene sequencing of atypical clinical isolates identified 27 new bacterial species associated with humans. Journal of Clinical Microbiology 42, 2197 - 2202. 
Fredericks, D. N. and Relman, D. A. (1996). Sequencebased identification of microbial pathogens: a reconsideration of Koch's postulates. Clinical Microbiology Review 9: 18 - 33.

Fulton, C. K. and Cooper, R. A. (2005). Catabolism of sulfamate by Mycobacterium sp. CF1. Environmental Microbiology 7, 378-381.

Ghosal, D., You, I. S., Chatterjee, D. K. and Chakrabarty, A. M. (1985). Microbial degradation of halogenated compounds. Science 228, 135 - 142.

Haggblom, M. M. (1992). Microbial breakdown of halogenated aromatic pesticides and related compounds. FEMS Microbiology Review 103, 29 - 72.

Hamid, A. A. A., Hamdan, S., Pakingking R. V. Jr. and Huyop, F. (2010). Identification of Pseudomonas sp. Strain S3 Based on Small Subunit Ribosomal RNA Gene Sequences. Biotechnology 9, 33 - 40.

Hardman, D. J. (1991). Biotransformation of halogenated compounds. Critical Review Biotechnology 11, 1 - 40.

Hareland, W. A., Crawford, R. L., Chapman, P.J. and Dagley, S. (1975). Metabolic function and properties of a 4- hydroxyphenylacetic acid 1-hydroxylase from Pseudomonas acidovorans. Journal of Bacteriology 121, 272-285.

Hejazi A. and Falkiner, F. R. (1997). Serratia marcescens. Journal of Medical Microbiology 46, 903 $-912$.

Ismail, S. N., Taha, A. M., Jing, N. H., Wahab, R. A., Hamid, A. A., Pakingking, R. V. Jr. and Huyop, F. (2008). Biodegradation of monochloroacetic acid by a presumptive Pseudomonas sp. strain R1 bacterium isolated from Malaysian paddy (rice) field. Biotechnology 7, 481 - 486.

Jing, N. H. and Huyop, F. (2007). Dehalogenation of chlorinated aliphatic acid by Rhodococcus sp. Asia Pacific Journal of Molecular Biology and Biotechnology 15, 147 - 151.

Jing, N. H. and Huyop, F. (2008). Enzymatic dehalogenation of 2,2 - dichloropropionic acid by locally isolated Methylobacterium sp. HJ1. Journal of Biological Science 8, 233 - 235.

Jing, N. H., Wahab, R. A., Taha, A. M., Rashid, N. A. A. and Huyop, F. ( 2008). A further characterization of 3 -chloropropionic acid dehalogenation from Rhodococcus sp. HJ1. Research Journal of Microbiology 3, 482 - 288.

Ke, T., Zhangfu, L., Qing, G., Yong, T., Hong, J., Hongyan, R., Kun, L. and Shigui, L. (2005). Isolation of Serratia marcescens as a chondroitinaseproducing bacterium and purification of a novel chondroitinase AC. Biotechnology Letters 27, 489 493.

Kolbert, C. P. and Persing, D. H. (1999). Ribosomal DNA sequencing as a tool for identification of bacterial pathogens. Current Opinion Microbiology 2, 299 - 305.

Lee, M. D., Odom, J. M. and Buchanan R. J. Jr. (1998). New perspectives on microbial dehalogenation of chlorinated solvents: Insights from the field. Annual Review Microbiology 52, 423 - 452.

Leisinger, T. and Bader, R. (1993). Microbial dehalogenation of synthetic organohalogen compounds: hydrolytic dehalogenase. Chimia 47, 116 $-121$.

Miller, J. M. and Rhoden, D. L. (1991). Preliminary evaluation of Biolog, a carbon source utilization method for bacterial identification. Journal of Clinical Microbiology 29, 1143-1147.

Raoult, D., Fournier, P. E. and Drancourt, M. (2004). What does the future hold for clinical microbiology. Nature Reviews Microbiology 2,151 - 159.

Rossello-Mora, R. and Amann, R. (2001). The species concept for prokaryotes. FEMS Microbiology Review 25, $39-67$.

Saitou, N. and Nei, M. (1987). The neighbor-Joining Method: A New Method for Reconstructing Phylogenetic Trees. Molecular Biology Evolution 4, 406 - 425.

Slater, J. H., Bull, A. T. and Hardman, D. J. (1995). Microbial Dehalogenation. Biodegradation 6 (3), 181 189.

Stager, C. E. and Davis, J. R. (1992). Automated systems for the identification of microorganisms. Clinical Microbiology Review 5, 302 - 327.

Sundaramoorthy, N., Yogesh, P. and Dhandapani, R. (2009). Production of prodigiosin from Serratia marcescens isolated from soil. Indian Journal of Science Technology 2 (10), 32 - 34.

Thasif, S., Hamdan, S. and Huyop, F. (2009). Degradation of $D, L-2$ - chloropropionic acid by bacterial dehalogenases that shows stereo specificity and its partial enzymatic characteristic. Biotechnology 8, 264 - 269.

Venil, C. K., Velmurugan, P. and Lakshmanaperumalsamy, P. (2009). Genomic environment of cueR and copA genes for prodigiosin biosynthesis by Serratia marcescens SB08. Romanian Biotechnological Letters 14 (6), 4812 4819.

Ventura, M. and Zink, R. (2002). Specific identification and molecular typing analysis of Lactobacillus johnsonii by using PCR-based methods and pulsedfield gel electrophoresis. FEMS Microbiology Letters 217: 141 - 154.

Wang, R. F., Cao, W. W. and Carnigla, C. E. (1995). Phylogenetic analysis of polycyclic aromatic hydrocarbon degrading mycobacteria by 16S rRNA sequencing. FEMS Microbiology Letters 130, 75 - 80.

World Health Organization (WHO) (1990). Report on TBEE, Environmental Health Criteria, International Program on Chemical Safety.

Zulkifly, A. H., Roslan, D. D., Hamid, A. A. A., Hamdan, S. and Huyop, F. (2010). Biodegradation of Low Concentration of Monochloroacetic Acid-Degrading Bacillus sp. TW1 Isolated from Terengganu Water Treatment and Distribution Plant. Journal of Applied Science 10, 2940 - 2944. 